\title{
A Comparative Study of Element Cycling in the Soil-Plant System: A Case Study of Shaly and Calcareous Soils, Southern Benue Trough, Nigeria
}

\author{
T. N. Nganje, C. I. Adamu \\ Department of Geology, University of Calabar, Calabar, Nigeria \\ Email: ntonzi@yahoo.com
}

Received 28 March 2013; revised 27 February 2014; accepted 21 April 2014

Copyright (C) 2014 by authors and Scientific Research Publishing Inc.

This work is licensed under the Creative Commons Attribution International License (CC BY). http://creativecommons.org/licenses/by/4.0/

\section{(c) () Open Access}

\section{Abstract}

This study focused on the cycling of major and trace elements in the soil-plant system in parts of Southern Benue Trough, Nigeria. Surface soil samples and cassava crop samples were collected from cultivated farmlands underlined by shaly and calcareous soils and were analysed using standard techniques. The results show that shaly soils are relatively acidic $(\mathrm{pH}, 4.8-6.6)$ with high level of organic matter content $(\mathrm{OM}, 3.2 \%-8.7 \%)$ compared to calcareous soils $(\mathrm{pH}, 5.6$ - 7.2; $0 \mathrm{M}$ $1.6 \%-7.0 \%$ ). The soils are enriched in elemental composition relative to the world average abundances in soil. The maximum levels of $\mathrm{K}, \mathrm{Al}$, and $\mathrm{Zn}$ were obtained from shaly soils. The computed accumulation factors are generally $<1$. Elemental levels decreased in the plant parts in the order tuber $>$ leaf $>$ stem. Significant correlation was obtained between elemental associations of calcareous surface soils compared to that of shaly soils. R-mode factor analysis revealed the controls of soil geochemistry to include lithology, anthropogenic and environmental factors. A stepwise linear regression analysis identified soil elemental component, $\mathrm{pH}$ and organic matter as some of the factors influencing soil-plant metal uptake.

\section{Keywords}

Soil Plant System, Cycling of Elements, Calcareous Soils, Shaly Soils, Southern Benue Trough, Nigeria 


\section{Introduction}

In the biosphere as a whole and in particular ecosystems, there are interrelationships between the content of mineral nutrients (elements) in the soil and plants. At a time when environmental quality and food protection are of major concern to man, a better understanding of the behavior of mineral nutrients, particularly the potential toxic elements in the soil-plant system seems to be particularly important.

The main source of mineral nutrients to plants is their growth media — soil, water and air from which elements are taken up by the root or the foliage. Some trace elements are essential as important constituents of pigments and enzymes, mainly $\mathrm{Cu}, \mathrm{Ni}, \mathrm{Zn}, \mathrm{Co}$, and Mo. However, all metals especially $\mathrm{Cd}, \mathrm{Pb}, \mathrm{Hg}, \mathrm{Cu}$ and $\mathrm{Se}$, are toxic at high concentration because of disrupting enzymes functions, replacing essential metals in pigment or producing reactive oxygen species [1].

Plant mineral nutrients may be released from anthropogenic or natural sources and follow the normal biogeochemical cycles. It is therefore reasonable to investigate their possible mobility, bioavailability and toxicity in living things [2]. Sedimentary rocks are much more important soil parent materials since they overlie most igneous formulations to account for over $75 \%$ of the outcrops of the earth's surface ([1] [3]). The natural availability of mineral nutrients to plant and ecosystem depends on the ease of weathering of rocks as well as their composition and the form of the nutrient, plant species, age etc.

Toxic levels of metals in soil can affect soil organisms with knock-on effect on soil organic matter decomposition, nitrogen mineralization and uptake which ultimately affects crop yield and quality.

Natural levels of trace elements in soil may build up due either to the local variation in geochemistry or anthropogenic activities. Though many studies have investigated the levels of trace elements in soils and edible plants from contaminated soils due to anthropogenic activities ([2] [4]) such studies are not common for native agricultural soils. Some workers have reported enhanced levels of metals on soil developed over shales [5]-[7] and ultrabasic \& basic igneous rocks [8].

Trace elements uptake by plants depends on both soil and plant factors such as source and chemical form of elements in soil, pH, Eh, organic matter, other constituent plant species, and plant age, among others. Consequently, element mobility and plant availability are very important when assessing the effect of soil elemental levels on plant metal uptake and related phytotoxic effect ([9] [10]). Interaction between elements occurring at the roots surface and within the plant can affect uptake, as well as translocation and toxicity [2]. Invariably, there is generally not a strong relationship between the concentration in soil and plants because it depends on so many different factors such as metal bioavailability, plant growth and metal distribution to plant parts [4].

In Nigeria sedimentary rocks including shales are distributed in the Benue Trough. The soils developed on these rocks are intensively cultivated for crop production. However, the distribution and fate of trace elements in the native agricultural soils and plants have not yet been evaluated. Therefore the present study was undertaken with the following objectives:

1) To determine the levels of some mineral nutrients in shaly and calcareous soil;

2) To determine the concentration of mineral nutrients in parts of Manihot esculenta (cassava leaves, stem and tubers);

3) To investigate the relationship between metal content of the cassava and those of the agricultural soil;

4) To compare the levels of metals in soil and plants on shaly soil with the calcareous soil.

Factor analysis was employed to discriminate similarities and differences in compositional patterns. Multiple regression analysis was also performed to investigate the factors controlling elemental uptake by plants. Finally metal transfer/accumulation factors were evaluated.

\section{Study Area}

The study area is situated between latitudes $5^{\circ} 00$ and $5^{\circ} 13 \mathrm{~N}$ and longitudes $8^{\circ} 00$ and $8^{\circ} 14 \mathrm{E}$ (Figure 1). It extends from Adiabo in Calabar through New Netim up to Mkapara village along Calabar-Itu highway in Odukpani Local Government Area of Cross River State, Southeastern Nigeria. Elevations are in the order of less than $10 \mathrm{~m}$ to $100 \mathrm{~m}$ above sea level. The area consists of low to moderate hills and valleys. The topography rises gradually in this area from the fluvial flood plain in the north to the basement complex. This type of geomorphology and topography coupled with clearing of land for farming activities makes this area prone to erosion.

The combination of heavy rains and good sunshine coupled with adequate soil nutrients has led to luxuriant vegetation which forms a thick cover in the study area. The vegetation is tropical rain forest and is made up of 
tall trees with evergreen leaves which forms canopies, prolific undergrowth of entangled shrubs, herbs and grasses which sometimes does not allow for easy accessibility. There are rapid developments of new settlements resulting from population growth and also clearing of vast hectares of land for farming of mostly edible plants which rather form the major occupation of the inhabitants. The major River systems draining the area include the Calabar, Great Kwa and Akpa Yafe Rivers and other meandering streams which forma network of tributaries that discharge into Cross River.

Geologically, the area of interest belongs to the Cretaceous sediments of Calabar Flank (Figure 1) in southern Benue Trough. Awi Formation of Aptian age [11] is the oldest recorded sedimentary unit in the area and is made of fluvio-deltaic sequence of cross bedded sandstones, siltstones, mudstones, conglomerates, claystones and shales. This unit overlies the Precambrian Oban massif unconformably Overlying the Awi Formation is the Albian Mfamosing limestones which is made up of of shallow marine-marine karstified platform carbonates characterised by thick dark-grey boundstone and grainstones, succeded by calccreous sandstones and black fissile calcareous shale [12]. A hard ground separates this carbonates build-up from a thick sequence of black, highly fissile shale, with minor intercalations of Marls, calcareous mudstones and grey shale beds known as Odukpani Formation [11] This Formation is well esposed at Ekekpon village and has been assigned a new name by Petters et al., 1995 [13] as Ekekpon shale Formation. This thick shale sequence spans from late Albian-CenomanianTuronian age. The thick marl unit (Coniacian in age) which is composed of thick marl beds intercalated with dark grey calcerous shale overlies the the Ekekpon shale Formation and is separated from the overlying Nkporo Formation by an unconformity. The Nkporo Formation which is of Late Campanian to Maastrichtian age is characterised by dark-grey, carbonaceous, friable shales with occasional beds of marlstones and gypsum [14]. The Nkporo shales are overlain by Tertiary-Recent sands of continental origin. These sands represent the Benin Formation.

\section{Materials and Methods}

\subsection{Sampling}

Surface soil samples (0 - $30 \mathrm{~cm}$ depth) were collected from soils developed from shale and limestone (Figure 1). The samples were taken from cultivated farmlands using a stainless steel hand auger $(2.5 \mathrm{~cm}$ I diameter) into plastic bags. Each soil sample comprised a composite of 5 sub-samples taken on an area of $1 \times 1 \mathrm{~m}^{2}$. Samples of cassava parts (leaves, stem and tubers) were also collected from the same location where the soil samples were collected. Samples were thereafter placed in polythene bags and properly labeled.

\subsection{Sample Preparation}

Soil samples were dried in an air circulating oven at $25^{\circ} \mathrm{C}$, disaggregate with agate mortar and pestle and sieved to $<2 \mathrm{~mm}$, homogenized and ground to powder ( $<180 \mathrm{~mm}$ ). The plants (leaves and stems) samples were washed with deionized water, dried in an air-circulating oven at $25^{\circ} \mathrm{C}$, and ground to fine powder. The tubers were carefully peeled, rinsed with tap water to remove surface dust, oven-dried at $25^{\circ}$ and ground to fine powder. After the laboratory preparation, the soil samples $<0.5 \mathrm{~g}$ were digested with a $4: 1$ mixture of concentrated nitric-perchloric acid on a hot plate and evaporated completely. The residue was leached with $2 \mathrm{M} \mathrm{HCl}$ [4] into well labeled and calibrated test-tubes and the solution made up to $10 \mathrm{ml}$ with deionized water. Plant samples were digested with concentrated nitric acid $\left(\mathrm{HNO}_{3}\right)$ and leached following the same procedure as that outlined above for soil samples.

\subsection{Analysis}

Leachates of soil samples and plant parts were analysed for trace (Fe, Co. $\mathrm{Cu}, \mathrm{Mo}, \mathrm{Pb}$ and $\mathrm{Zn}$ ) and major elements (Ca, K, Al and Al) using ICP-MS (Perkin Elmer Elan 6000/9000) in Acme Analytical Laboratories Ltd., Vancouver-Canada. The $\mathrm{pH}$ of soil was determined by $\mathrm{pH}$ meter in the field. The $\mathrm{pH}$ of the soil samples were measured on a slurry formed by mixing $0.5 \mathrm{gm}$ of an air dried $<2 \mathrm{~mm}$ grain size sample with $10 \mathrm{ml}$ distilled water. After mixing for five seconds the slurry was left to stand for 5 minutes before the $\mathrm{pH}$ was measured using a calomel glass electrode $\mathrm{pH}$ meter. The $\mathrm{pH}$ in each case was taken to 0.01 units after the reading had stabilized for one minute. Organic matter contents of soil samples were estimated from loss on ignition (LOI). About $5 \mathrm{gm}$ of each sample was ignited in a muffled furnace at $550^{\circ} \mathrm{C}$ for 24 hours, removed, allowed to cool and weighed. 


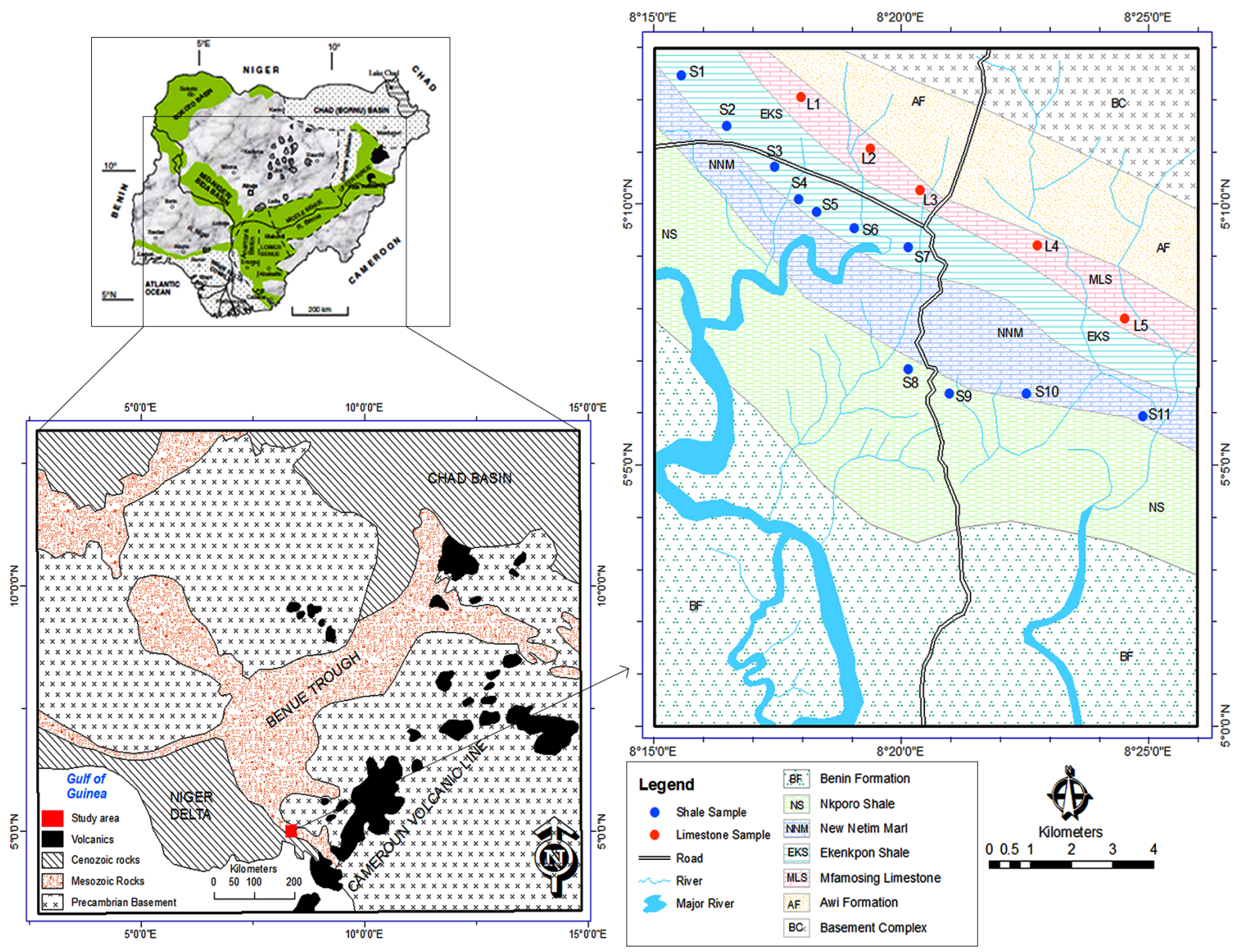

Figure 1. Geologic map of the study area showing sample location: modified after Geological Survey of Nigeria [18].

The LOI was calculated as weight loss after ignition expressed as per cent of the initial 5 gm of sample. The organic matter content of the soil was estimated from loss on ignition (LOI) [15]. A vigorous quality control programme was used to assess the accuracy and precision of the chemical data. The programme included reagent blanks, replicate and duplicate samples as well as in-house reference materials. The analytical variances of data were $<10 \%$.

\subsection{Statistical Analysis}

Univariate statistical methods including mean, range and percentages were employed to analyze data on individual element concentration, which can be useful in exploratory and descriptive methods as were as population groupings. Multi-variate statistics methods including spearman correlation, factor and regression analyses were used to determine detailed interrelationships and associations of variables as well as the factors controlling the chemistry of soil samples respectively. Spearman correlation, factor and regression analyses methods were carried out using SPSS version 10 and data tools analysis software.

\section{Results and Discussion}

\subsection{Soil pH and LOI}

The soil pH in the surface soil $(0-30 \mathrm{~cm})$ ranged from 4.8 - 6.6 and 7.2 - 8.5 with mean values of 5.7 and 6.6 from shaly and calcareous soils respectively (Table 1). This revealed the moderately acidic nature of shaly soils and the neutral-alkaline nature of calcareous soils. The LOI was generally low $<10 \%$ but relatively higher in the shaly soil indicating higher organic matter content which reflected the carbonaceous nature of the shale rocks. Lower values of LOI most probably reflect minimal leaching. 
Table 1. Metal concentration, pH and LOI of soil sample in the southern trough, Nigeria.

\begin{tabular}{|c|c|c|c|c|c|c|}
\hline \multirow{2}{*}{ Parameter } & \multirow{2}{*}{$\begin{array}{c}\text { Shaly Soil } \\
\text { (SS) n = 10 } \\
\text { Mean (Range) }\end{array}$} & \multirow{2}{*}{$\begin{array}{l}\text { Calcareous Soil } \\
\text { (CS) n = 5 } \\
\text { Mean (Range) }\end{array}$} & \multirow{2}{*}{ NRS } & \multirow{2}{*}{ INV } & \multicolumn{2}{|c|}{$\begin{array}{c}\text { Accumulation } \\
\text { Factor (AF) }\end{array}$} \\
\hline & & & & & SS & CS \\
\hline $\mathrm{pH}$ & $5.7(4.8-66)$ & $6.6(8.5-7.2)$ & $6.5-8.5$ & NA & NA & NA \\
\hline LOI (\%) & $6.69(3.9-7.8)$ & $4.08(1.6-7.0)$ & NA & NA & NA & NA \\
\hline Са (\%) & $1.50(0.6-2.3)$ & $2.00(1.6-3.8)$ & 1.37 & NA & 0.21 & 0.11 \\
\hline K (\%) & $2.56(1.7-3.6)$ & $1.66(1.2-2.2)$ & 1.36 & NA & 0.07 & 0.33 \\
\hline $\mathrm{Al}(\%)$ & $6.93(5.2-8.2)$ & $4.40(2.7-6.3)$ & 7.13 & NA & 0.004 & 0.004 \\
\hline $\mathrm{Na}(\%)$ & $0.86(0.5-1.4)$ & $1.38(1.0-2.4)$ & 0.63 & NA & 0.19 & 0.03 \\
\hline $\mathrm{Fe}(\%)$ & $5.07(1.8-7.0)$ & $2.90(1.2-4.3)$ & $1.4-2.8$ & 6.6 & 0.003 & 0.007 \\
\hline $\mathrm{Cu}(\mathrm{mg} / \mathrm{kg})$ & $91.9(69-116)$ & $72.8(33-112)$ & $2-200$ & 190 & 0.03 & 0.02 \\
\hline Zn (mg/kg) & $332(196-562)$ & $252(192-306)$ & $10-300$ & 720 & 0.04 & 0.03 \\
\hline $\mathrm{Pb}$ (mg/kg) & $146(74-253)$ & $59(24-96)$ & $2-200$ & 530 & 0.003 & 0.002 \\
\hline Co (mg/Kg) & $69.4(36-96)$ & $92(76-112)$ & 1.70 & 240 & 0.003 & 0.002 \\
\hline Mo (mg/kg) & $22.7(8-48)$ & $57(40-82)$ & NA & NA & 0.13 & 0.03 \\
\hline
\end{tabular}

NRS = Normal range in soil (4), INV = Intervention value (21).

\subsection{Soil Macronutrients}

The analytical result of soil macronutrients is presented in Table 1 . The table shows that mean (range) values of the major elements were $1.5(0.6$ - 2.3) and 2.6 (1.6 - 3.3)\% (Ca), 2.56 (1.76 - 3.6) and $1.66(1.2$ - 2.2)\% (K), 6.93 (5.2 - 8.2) and $4.40(2.76$ - 6.3)\% (Al), $0.86(0.5$ - 1.4) and $1.38(1-2.4) \% \mathrm{Na}$ in surface shaly and calcareous soils respectively. The soil composition revealed the elevated levels of $\mathrm{Ca}$ and $\mathrm{Na}$ in calcareous soil relative to shaly soil. While $\mathrm{K}$ and $\mathrm{Al}$ are enriched in shaly soil relative to calcareous. This variation of soil elemental composition between soil types was attributed to the geochemical composition of parent rock material. Soils derived from these rocks tend to reflect their geochemical composition. The lower levels of $\mathrm{Na}$ and $\mathrm{K}$ in both soil types reflect the mobility of these alkali metals in tropical climate. $\mathrm{K}$ is commonly absorbed by clay and organic matter in soil [1]. The low organic matter content of the surface soils is a reflection of their low sorption capacity.

\subsection{Soil Micronutrients}

Mean concentrations of most trace elements ( $\mathrm{Fe}, \mathrm{Cu}, \mathrm{Zn}$ and $\mathrm{Pb}$ ) in the shaly soils were higher in variation than those of the calcareous soils (Table 1). However, the mean concentrations of Mo and Co in calcareous soils are higher than those in shaly soils. This may again reflect the composition of the parent materials. Shales are commonly associated with high levels of trace metals [5]. The higher levels of Mo and to lesser degree Co in calcareous soil may reflect the antiphatic relationship between these trace elements and the other elements in oxidizing environment [1].

\subsection{Macro and Micro Nutrients in Plant Parts}

The concentration of major elements varied between sample sites and among plant parts. Higher mean values of major elements (Ca, $\mathrm{K}, \mathrm{Al}, \mathrm{Na}$, and $\mathrm{Fe}$ ) were obtained in plant parts from limestone area except for $\mathrm{Al}$ in cassava stem and tubers which were slightly higher in the shale area (Table 2). This variation reveals that macronutrients are more available in the calcareous area. On the contrary, higher mean levels of trace elements in plant parts were obtained in the shale area except for $\mathrm{Cu}$ in stem, $\mathrm{Zn}$ and Mo in leaf. This indicates the relative higher bioavailability of trace elements in shaly soil than in calcareous soil. The differential uptake of elements from shaly and calcareous soils (Table 1) may reflect the influence of trace elements on major element uptake and vice versa [2]. 


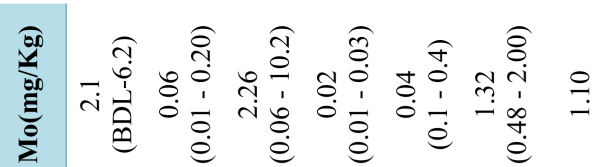

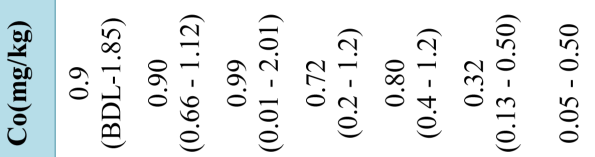

$$
\begin{aligned}
& \text { 产 }
\end{aligned}
$$

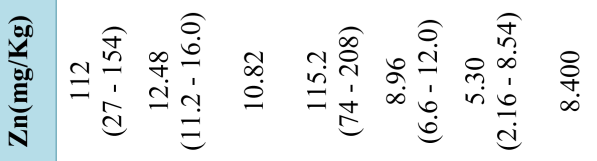

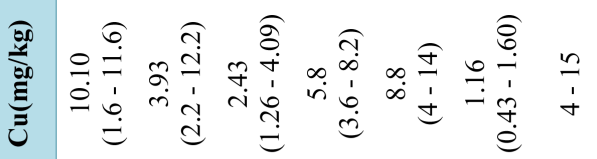

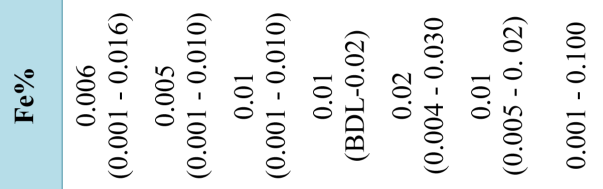

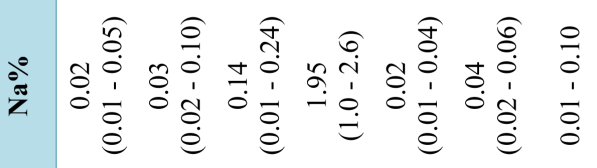

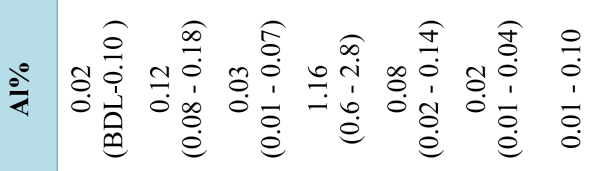

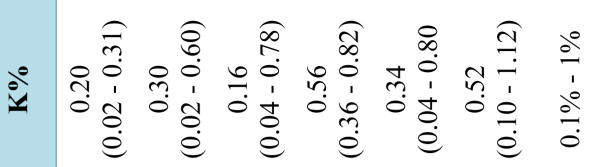

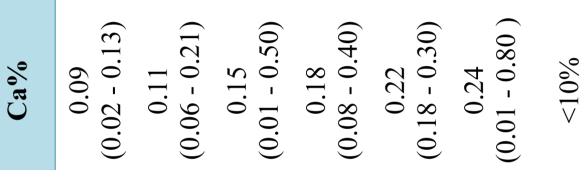

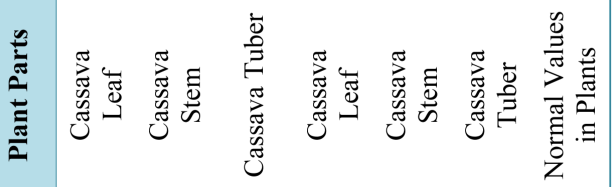

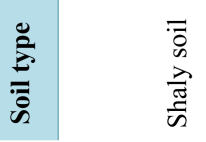

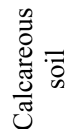




\section{Enrichment Assessment}

A comparison of the levels of metals in the soils with normal range values in soil (4) revealed that shaly soils are enriched in $\mathrm{Fe}, \mathrm{Zn}, \mathrm{Pb}$ and $\mathrm{Co}$ while the calcareous soils are enriched in $\mathrm{Ca}, \mathrm{Na}$, and Co relative to the normal range values in soils (Table 1). But the enrichment does not reach the intervention limit. The environmental implication of the enhanced levels of these trace elements in the soils is that any anthropogenic inputs of these potential pollutants may lead to serious soil contamination. The levels of the other trace elements (Cu and $\mathrm{Mo})$ are within the normal range found in soils and do not pose any serious environmental threat in the study area.

Most elements in plant parts in the present study were found at concentrations within the same order of magnitude as crops growing on uncontaminated soils [4] except for $\mathrm{Al}$ (mean 1.16\%) in cassava leaves from the shale area; Co in leaves $(\mathrm{x}=0.90 \mathrm{mg} / \mathrm{kg})$, stem $(0.90 \mathrm{mg} / \mathrm{kg})$ and tubers $(0.99 \mathrm{mg} / \mathrm{kg})$ from calcareous soils. This may reflect variations in bioavailability, growth rate, and emission rate among other geochemical controls [3].

\subsection{Correlation Analysis}

In order to estimate the degree of interrelationship between parameters in a manner not influenced by measurement units, the correlation coefficient (r), which is the ratio of the covariance of two variances to the product of their standard deviation, was used. The correlation coefficient is a unit-less ratio number, which ranges between -1 and +1 , where +1 , indicates a correlation of a perfect direct rectilinear relationship between two variables and a correlation of -1 indicates that the variables have an inverse rectilinear relationship. Between the two extremes is a spectrum of less-than-perfect relationships including zero, which indicates complete lack of linear relationship. The Pearson (or product moment) correlation analysis was used in estimating the degree of relationship between constituent variables in the soil samples. Spearman correlation analysis was performed using SPSS software. Table 3 and Table 4 show the correlation matrices for soil parameters from the shale and the limestone areas respectively. Table 3 revealed strong positive correlation at $\mathrm{p}<0.05$ for $\mathrm{Fe}$ with $\mathrm{Cu}(\mathrm{r}=0.799)$ and Co $(r=0.79)$ in shaly soil. This most probably reflects the scavenging effect of Fe on these mobile elements [15]. For the calcareous soil, strong positive correlations at $\mathrm{p}<0.05$ were observed between $\mathrm{Al}$ and $\mathrm{LOI}, \mathrm{Pb}$ and $\mathrm{K}, \mathrm{Fe}$ and $\mathrm{Na}$, and $\mathrm{Mo}$ and $\mathrm{Al}(\mathrm{r}=0.96)$. The relation between $\mathrm{Pb}$ and $\mathrm{K}, \mathrm{Fe}$ and $\mathrm{Na}$ may be due to cation exchange processes.

Table 3. Correlation coefficient matrix of surface soil $(0-15 \mathrm{~cm})$ in shale area.

\begin{tabular}{|c|c|c|c|c|c|c|c|c|c|c|c|c|}
\hline \multicolumn{13}{|c|}{ Correlations } \\
\hline & $\mathrm{pH}$ & OM & $\mathrm{Ca}$ & $\mathrm{K}$ & $\mathrm{Al}$ & $\mathrm{Na}$ & $\mathrm{Fe}$ & $\mathrm{Cu}$ & $\mathrm{Zn}$ & $\mathrm{Pb}$ & Co & Mo \\
\hline $\mathrm{pH}$ & 1 & & & & & & & & & & & \\
\hline $\mathrm{OM}$ & 0.291 & 1 & & & & & & & & & & \\
\hline $\mathrm{Ca}$ & 0.081 & -0.503 & 1 & & & & & & & & & \\
\hline K & 0.051 & 0.461 & -0.447 & 1 & & & & & & & & \\
\hline $\mathrm{Al}$ & 0.317 & -0.066 & 0.114 & -0.493 & 1 & & & & & & & \\
\hline $\mathrm{Na}$ & 0.495 & 0.151 & -0.177 & -0.488 & 0.558 & 1 & & & & & & \\
\hline $\mathrm{Fe}$ & -0.398 & 0.025 & -0.035 & 0.037 & -0.42 & 0.356 & 1 & & & & & \\
\hline $\mathrm{Cu}$ & -0.559 & -0.04 & -0.033 & -0.212 & -0.139 & 0.175 & $0.799^{* *}$ & 1 & & & & \\
\hline $\mathrm{Zn}$ & 0.006 & 0.237 & 0.202 & -0.406 & 0.301 & 0.112 & -0.338 & 0.021 & 1 & & & \\
\hline $\mathrm{Pb}$ & 0.404 & 0.267 & 0.162 & -0.032 & -0.27 & 0.09 & -0.42 & -0.44 & 0.586 & 1 & & \\
\hline Co & -0.425 & 0.399 & -0.263 & 0.472 & -0.62 & 0.631 & $0.785^{* *}$ & 0.608 & 0.099 & 0.124 & 1 & \\
\hline Mo & 0.107 & 0.184 & -0.413 & 0.446 & 0.384 & 0.077 & -0.51 & 0.286 & 0.181 & 0.328 & 0.261 & 1 \\
\hline
\end{tabular}

\footnotetext{
${ }^{* * *}$ Correlation is significant at the 0.01 level (2-tailed).
} 
Table 4. Correlation coefficient matrix of surface soil $(0-15 \mathrm{~cm})$ in limestone area.

\begin{tabular}{|c|c|c|c|c|c|c|c|c|c|c|c|c|}
\hline \multicolumn{13}{|c|}{ Correlations } \\
\hline & $\mathbf{p H}$ & OM & $\mathrm{Ca}$ & $\mathbf{K}$ & Al & $\mathrm{Na}$ & $\mathbf{F e}$ & $\mathbf{C u}$ & Zn & $\mathbf{P b}$ & Co & MO \\
\hline pH & 1 & & & & & & & & & & & \\
\hline OM & 0.457 & 1 & & & & & & & & & & \\
\hline Ca & -0.191 & -0.399 & 1 & & & & & & & & & \\
\hline $\mathbf{K}$ & 0.176 & 0.2 & -0.145 & 1 & & & & & & & & \\
\hline Al & -0.442 & $-0.921^{*}$ & 0.441 & 0.179 & 1 & & & & & & & \\
\hline $\mathrm{Na}$ & -0.78 & -0.091 & 0.389 & -0.514 & -0.019 & 1 & & & & & & \\
\hline $\mathbf{F e}$ & 0.689 & -0.023 & -0.542 & 0.278 & 0.019 & $-0.942^{*}$ & 1 & & & & & \\
\hline $\mathbf{C u}$ & 0.692 & 0.627 & -0.243 & -0.447 & -0.828 & -0.176 & 0.229 & 1 & & & & \\
\hline $\mathbf{Z n}$ & -0.54 & 0.004 & -0.156 & 0.707 & 0.292 & 0.129 & -0.244 & -0.766 & 1 & & & \\
\hline $\mathbf{P b}$ & -0.059 & -0.319 & -0.16 & $-0.898^{*}$ & -0.073 & 0.188 & 0.117 & 0.403 & -0.695 & 1 & & \\
\hline Co & 0.228 & -0.643 & -0.088 & 0.267 & 0.672 & -0.698 & 0.751 & -0.345 & -0.046 & 0.09 & 1 & \\
\hline Mo & -0.307 & -0.863 & 0.62 & 0.199 & $0.967 *^{*}$ & -0.048 & -0.015 & -0.741 & 0.189 & -0.16 & 0.628 & 1 \\
\hline
\end{tabular}

${ }^{*}$ Correlation is significant at the 0.05 level (2-tailed). ${ }^{* *}$ Correlation is significant at the 0.01 level (2-tailed).

\subsection{Factor Analysis (FA)}

Factor analysis is a method of reducing complexity of a given set of inter-correlated data by accounting for the observed correlations among the variables in the terms of the fewest possible number of underlying factors (16). R-mode factor analysis is a multivariate statistical technique that is widely used to aid the interpretation of geochemical data and enhances subtle but significant single-element anomalies. Furthermore, it can reveal the factors that are present and how their influence varies across any given area (17). The main aim of factor analysis is to reveal the underlying relations that are presumed to exist within a set of multivariate observations (16). The analysis groups related variables into principal associations (factors) based on their mutual correlation coefficients and these associations may be interpreted in terms of mineralization, lithologic, anthropogenic and environmental processes.

R-mode factor analysis was employed in the present study to process data as an effort to determine the sources of incipient element concentration, as well as, the factors controlling such. The computation was by the statistical package for social sciences software (SPSS). The data was first treated to a condescriptive analysis, during which all data that were log normally distributed were identified and log normally transformed using Kaiser Normalization. The data were then standardized and scaled to equalize the influence of parameters with small and large variation using the z-transformation. The $\mathrm{z}$ scores were input for factor analysis (16). The output factor solutions provide information on 1) loading - the strength of a particular parameter in a factor, 2) communality - the amount of total variability of each parameter explained in a given factor model, and 3) eigenvalues (expressed in percent) - the amount of total data explained by each model.

Three factors (Table 5) were found to account for $88.1 \%$ of data variance in the soils from the limestone area.

Factor 1: $\mathrm{Al}, \mathrm{Mo}, \mathrm{Cu}$ and $\mathrm{LOI}$ account for $35.3 \%$ of data variance with high positive loadings on $\mathrm{Al}$ and $\mathrm{Mo}$ and negative loadings on $\mathrm{Cu}$ and LOI. This is considered an environmental factor that explains the complexity of $\mathrm{Cu}$ by organic matter. This factor is an index of the natural process of soil formation. The metals were most probably released from the parent (shale and limestone) rocks by chemical weathering. The exchangeable bases were leached into the subsurface while the $\mathrm{Al}$ formed insoluble amorphous oxides. While the decomposition of plant parts formed the soil organic matter (LOI). The trace metals were specifically adsorbed or chemisorbed onto the Al-oxide (Mo) and onto soil organic matter $(\mathrm{Cu})$ phases.

Factor 2: pH, Co, Na and Fe. This factor accounts for $28.8 \%$ of data variance and loads positively on $\mathrm{pH}$ and $\mathrm{Co}$ and negatively on $\mathrm{Na}$ and $\mathrm{Fe}$. This factor is also an index of natural processes. The factor is considered an 
Table 5. R-mode Variamax factor matrix of soil.

\begin{tabular}{cccc}
\hline & \multicolumn{3}{c}{ Rotated Component Matrix $^{\mathrm{a}}$} \\
& \multicolumn{3}{c}{ Component } \\
\cline { 2 - 4 } $\mathrm{pH}$ & 0.115 & $\mathbf{2}$ & $\mathbf{3}$ \\
$\mathrm{OM}$ & 0.148 & 0.139 & -0.920 \\
$\mathrm{Ca}$ & 0.510 & 0.074 & 0.856 \\
$\mathrm{~K}$ & 0.844 & 0.254 & 0.849 \\
$\mathrm{Al}$ & 0.386 & -0.861 & 0.031 \\
$\mathrm{Na}$ & -0.836 & -0.437 & 0.321 \\
$\mathrm{Fe}$ & 0.806 & -0.448 & 0.372 \\
$\mathrm{Cu}$ & 0.689 & 0.711 & -0.011 \\
$\mathrm{Zn}$ & 0.240 & 0.918 & -0.080 \\
$\mathrm{~Pb}$ & 0.975 & -0.111 & 0.135 \\
$\mathrm{Co}$ & -0.130 & 0.606 & -0.741 \\
$\mathrm{Mo}$ & -0.143 & -0.924 & -0.159 \\
\hline
\end{tabular}

Extraction Method: Principal Component Analysis. Rotation Method: Va-

rimax with Kaiser Normalization. ${ }^{\mathrm{a}}$ Rotation converged in 5 iterations.

alkalising factor and reflects effects of hydrolysed $\mathrm{Na}$ and Fe on alkalinity with subsequent immobilization of Co. The source of the metals ( $\mathrm{Co}, \mathrm{Na}$ and $\mathrm{Fe}$,) is also geogenic. The alkalinity of the soil most probably reflects the calcareous parent rocks.

Factor 3: $\mathrm{Pb}, \mathrm{Zn}$ and $\mathrm{K}$. This factor has positive loading on $\mathrm{Pb}$ and negative loading on $\mathrm{Zn}$ and $\mathrm{K}$ and accounts for about $24 \%$ of data variance. This factor is an index of anthropogenic processes. The antipathetic association of chalcophile metals ( $\mathrm{Zn}$ and $\mathrm{Pb}$ ) that are known to be geochemically similar (1) suggests anthropogenic controls on this factor. The $\mathrm{Pb}$ is most probably from atmospheric emissions whereas; $\mathrm{Zn}$ and $\mathrm{K}$ are from the indiscriminate application of fertilizer in the area. The antipathetic loading of $\mathrm{Zn}$ and $\mathrm{K}$ on this factor reflects their different geochemical control and/or source from $\mathrm{Pb}$.

\subsection{Regression Analysis}

This was applied to find the dominant factors influencing soil-metal uptake by plants and to predict metal levels in plants. The regression equation was calculated using statistical package for the soil sciences (SPSS). The result of linear multiple regressions (Table 6) show that $\mathrm{Zn}$ and Ca in cassava leaves from calcareous soils, $\mathrm{Ca}$ and $\mathrm{Na}$ in stem from shaly soil and $\mathrm{Ca}, \mathrm{Fe}, \mathrm{Cu}$ and $\mathrm{Pb}$ in cassava leaves from calcareous soil correlated negatively with corresponding metals in soil. This implies that total metal concentration in the soils is not the main factor controlling the metal concentration in plants The $\mathrm{pH}$ is the main factor controlling plant metal uptake from calcareous soil while organic matter and soil metal content are dominant controlling factors in the shaly soils [18] described that the organic horizon of soil is the important accumulator of trace metals and the barrier against transport of pollutants to lower depths. Thus, in the study area the shaly soil has greater exchangeable acidity and metal storage in the surface layer than the calcareous soil. Soil $\mathrm{pH}$ is a general indicator of acidity in the soil [10] and according to [19] the acidity $(\mathrm{pH})$ is the most important soil characteristic that modulates bioavailability of trace metals by affecting both the chemical speciation of metals in soil and the metal binding to the active sites on biota. Besides soil $\mathrm{pH}$, metal bioavailability also depends to a certain extent on the soil.

\section{Conclusion}

This pilot study has provided base level of elemental composition of soil-plant system in the study area. This can serve in proper farm management and practice such as proper application of fertilizer and manure. Results of 
Table 6. Results of stepwise multiple regression analysis.

\begin{tabular}{|c|c|}
\hline \multicolumn{2}{|l|}{ Shale Area } \\
\hline \multicolumn{2}{|l|}{ Cassava Leaf } \\
\hline$(\mathrm{Zn}) \mathrm{p}=215.834-0.186(\mathrm{Zn}) \mathrm{s}-8.746 \mathrm{pH}+1.124 \mathrm{OM}$ & $\mathrm{R}^{2}=0.688$ \\
\hline$(\mathrm{Ca}) \mathrm{p}=-0.125-0.034(\mathrm{Ca}) \mathrm{s}+0.052 \mathrm{pH}-0.005 \mathrm{OM}$ & $\mathrm{R}^{2}=0.709$ \\
\hline$(\mathrm{Co}) \mathrm{p}=3.474+0.000(\mathrm{Mo}) \mathrm{s}-0.249 \mathrm{pH}-0.159 \mathrm{OM}$ & $R^{2}=0.986$ \\
\hline \multicolumn{2}{|l|}{ Stem } \\
\hline$(\mathrm{Ca}) \mathrm{p}=2.348-1.65 \mathrm{pH}-143 \mathrm{OM}-252 \mathrm{Ca}(\mathrm{s})$ & $\mathrm{R}^{2}=0.520$ \\
\hline$(\mathrm{K}) \mathrm{p}=-3.259+0.37 \mathrm{pH}+0.244 \mathrm{OM}-0.038 \mathrm{~K}(\mathrm{~s})$ & $\mathrm{R}^{2}=1.000$ \\
\hline$(\mathrm{Al}) \mathrm{p}=-0.178+0.012 \mathrm{pH}+0.020 \mathrm{OM}+0.018 \mathrm{Al}(\mathrm{s})$ & $\mathrm{R}^{2}=0.878$ \\
\hline$(\mathrm{Na}) \mathrm{p}=-0.096+0.028 \mathrm{pH}-0.012 \mathrm{OM}+0.027 \mathrm{Na}(\mathrm{s})$ & $\mathrm{R}^{2}=0.878$ \\
\hline \multicolumn{2}{|l|}{ Limestone Area } \\
\hline \multicolumn{2}{|l|}{ Cassava Leaf } \\
\hline$(\mathrm{Ca}) \mathrm{p}=0.849-0.26 \mathrm{pH}-0.34 \mathrm{OM}-0.318 \mathrm{Ca}(\mathrm{s})$ & $\mathrm{R}^{2}=0.900$ \\
\hline$(\mathrm{Fe}) \mathrm{p}=0.038-0.002 \mathrm{pH}-0.00 \mathrm{OM}-0.003 \mathrm{Fe}(\mathrm{s})$ & $\mathrm{R}^{2}=0.835$ \\
\hline$(\mathrm{Cu}) \mathrm{p}=14.535-1.958 \mathrm{pH}-0.788 \mathrm{OM}-0.101 \mathrm{Cu}(\mathrm{s})$ & $\mathrm{R}^{2}=1.000$ \\
\hline$(\mathrm{Pb}) \mathrm{p}=0.441+0.186 \mathrm{pH}-0.112 \mathrm{OM}-0.001 \mathrm{~Pb}(\mathrm{~s})$ & $\mathrm{R}^{2}=0.950$ \\
\hline
\end{tabular}

this study indicate that the shaly soil have more retention capacity for the nutrients than the calcareous soils. The soils have greater bioavailability of the macro- and micronutrients to most plant roots and the order of bioavailability in plant parts is leaf $>$ stem $>$ root.

\section{References}

[1] Siegel, F.R. (2002) Environmental Geochemistry of Potential Toxic Metals. Springer, Heidelberg. http://dx.doi.org/10.1007/978-3-662-04739-2

[2] Kabata-Pendias, A. and Pendias, H. (2002) Trace Elements in Soils and Plants. Lewis, Boca Raton.

[3] Cox, P.A. (1995) The Elements on Earth, Inorganic Chemistry in the Environment. Oxford University Press Inc., New York.

[4] Bowen, H.J.M. (1979) Environmental Chemistry of the Elements. Academic Press, New York.

[5] Fang, W., Hu, R. and We, P. (2001) Influence of Blank Shales on Soils and Edible Plants in the Ankang Area, Shaanxi Province, P. R. of China. Environmental Geochemistry and Health, 24, 36-46.

[6] Peng, B., Wu, F.-C., Xiao, M.L., Xie, S.R., Lu, H.Z. and Dai, Y. (2005) Resources Function and Environment Effects of Black Shales. Bulletin of Mineralogy, Petrology and Geochemistry, 24, 153-158.

[7] Kwong, Y.T.J., Whitely, G. and Roach, P. (2009) Natural Acid Rock Drainage Associated with Black Shale in the Yukon Territory, Canada. Applied Geochemistry, 24, 221-231. http://dx.doi.org/10.1016/j.apgeochem.2008.11.017

[8] Thornton, I. and Plant, J. (1980) Regional Geochemical Mapping and Health in the UK. Journal of Geological Society of London, 137, 575-586. http://dx.doi.org/10.1144/gsjgs.137.5.0575

[9] Eide, D.J. (2004) The SLC39 Family of Metal Ion Transporters. Pflügers Archiv—European Journal of Physiology, 447, 796-800.

[10] Nwachukwu, M.A., Feng, H., Alinnor, J. and Nwachukwu, M. (2011) A Comparative Analysis of Trace Metal Pollution Parity between Sandy and Shaly Soils: Evidence from Two Mechanic Villages in the Imo River Basin. Environmental Earth Sciences, 65, 765-774. http://dx.doi.org/10.1007/s12665-011-1122-9

[11] Adeleye, D.R. and Fayose, E.A. (1978) Stratigaphy of the Type Section of Awi Formation Odukpani Area, Southeastern Nigeria. Nigerian Journal of Mining and Geology, 15, 33-37.

[12] Petters, S.W. and Ekweozor, C.N. (1982) Petroleum Geology of Benue Trough and Southeastern Chad Basin, Nigeria. 
AAPG Bulletin, 66, 1141-1149.

[13] Petters, S.W., Nyong, E.E., Akpan, E.B. and Essein, N.U. (1995) Lithostratigraphy Revision of the Calabar Flank. In: Okereke, C.S., Ed., 31st Annual Conference, Calabar, 12-16 March 1995, Nigerian Mining and Geoscience Society, 67.

[14] Reyment, R.A. (1965) Aspects of Geology of Nigeria. Ibadan University Press, Ibadan.

[15] Nganje, T.N., Adamu, C.I. and Ukpong, E.E. (2010) Heavy Metal Concentration in Soils and Plants in the Vicinity of Arufu Lead-Zinc Mine, Middle Benue Trough, Nigeria. Chinese Journal of Geochemistry, 29, 167-174. http://dx.doi.org/10.1007/s11631-010-0167-x

[16] Joe, A.J. (2006) Fundamental Statistics. Kraft, Ibadan.

[17] Edet, A.E., Markel, B.I. and Offiong, O.E. (2003) Trace Element Hydrochemical Assessment of the Calabar Coastal Plain Aquifer, Southeastern Nigeria: Using Statistical Methods. Environmental Geology, 44, 137-149.

[18] Koptsik, S.V. and Koptsik, G.N. (2001) Soil Pollution Patterns in Terrestrial Ecosystems of the Kola Penninsula. Proceedings of 10th International Soil Conservation Organization, 24-29 May 1999, West Lafayette, 212-216.

[19] Weng, L.P., Wolthoorn, A., Lexmond, T. M., Temminghoff, E.J.M. and Van Riemsdijk, W.H. (2004) Understanding the Effects of Soil Characteristics on Phytotoxicity and Bioavailability of Nickel Using Speciation Models. Environmental Science \& Technology, 38, 156-162. http://dx.doi.org/10.1021/es030053r

[20] Geological Survey of Nigeria (1974) Geological Map of Nigeria: Scale 1:2,000,000.

[21] Bhattacharya, A., Routh, J., Jack, G., Bhattacharya, P. and Mörth, M. (2006) Environmental Assessment of Abandoned Mining Tailings in Adak, Västerbotten District (Northern Sweden). Applied Geochemistry, 21, 1760-1780. http://dx.doi.org/10.1016/j.apgeochem.2006.06.011 